\title{
DISTRIBUSI TEMPAT PERINDUKAN AEDES Sp. PADA DATARAN TINGGI DAN RENDAH DI KELURAHAN TULUNGREJO DAN KELURAHAN GIRIPURNO KECAMATAN BUMIAJI KOTA BATU TAHUN 2017
}

Muhammad Haris Pamungkas, Ngadino, Sudjarwo

\begin{abstract}
ABSTRAK
Pada tingkat ketinggian tempat yang berbeda dapat mempengaruhi suhu dan kelembaban udara suatu wilayah. Berdasarkan Dirjen P2PL Kementerian Kesehatan RI di tempat dengan ketinggian lebih dari 1.000 mdpl semestinya tidak ditemukan nyamuk Aedes aegypti yang merupakan vektor penular penyakit Demam Berdarah Dengue karena pada ketinggian tersebut suhu udara terlalu rendah sehingga tidak memungkinkan bagi kehidupan nyamuk.

Tujuan penelitian ini untuk mengetahui distribusi tempat perindukan Aedes $s p$. pada dataran tinggi dan dataran rendah Kelurahan Tulungrejo dan Kelurahan Giripurno, Kecamatan Bumiaji, Kota Batu.

Jenis penelitian ini adalah survei deskriptif dengan pendekatan cross sectional. Analisis data yang digunakan yaitu analisis spasial berupa peta digital Kota Batu dan data titik koordinat rumah sampel yang diperoleh dari pengukuran menggunakan alat GPS. Data yang diperoleh diolah menjadi peta baru sebagai informasi distribusi tempat perindukan Aedes sp.

Hasil pengamatan di Kelurahan Tulungrejo didapatkan nilai HI sebesar 1,7\%, CI sebesar 2,22\%, dan BI sebesar 3,39 sehingga tergolong dalam kategori kepadatan rendah (density figure $=1$ ). Pada wilayah Kelurahan Giripurno didapatkan nilai HI sebesar $15,25 \%$, CI sebesar 13,51\%, dan BI sebesar 16,95 sehingga tergolong dalam kategori kepadatan sedang (density figure $=3$ ). Telah terjadi perubahan perilaku berkembangbiak nyamuk Aedes sp. di Kelurahan Tulungrejo. Nyamuk Aedes sp. sudah mampu bertahan hidup dan berkembangbiak meskipun berada di wilayah dataran tinggi lebih dari 1.000 mdpl.

Perlu dilakukan penelitian lebih lanjut mengenai faktor-faktor yang mempengaruhi sebaran perindukan nyamuk Aedes $s p$. di wilayah dataran tinggi $>1.000$ mdpl. Serta perlu adanya kewaspadaan dini pencegahan DBD di wilayah dataran tinggi.
\end{abstract}

Kata kunci: distribusi larva Aedes sp., perbedaan dataran

\section{PENDAHULUAN}

Hingga sampai saat ini Demam Berdarah Dengue (DBD) masih menjadi masalah kesehatan yang utama di dunia. Demam Berdarah Dengue banyak ditemukan baik di daerah tropis maupun sub-tropis. Diperkirakan setiap tahun sekitar 50 juta manusia terinfeksi virus dengue. Terhitung sejak tahun 1968 hingga tahun 2009, World Health Organization (WHO) mencatat negara Indonesia sebagai negara dengan kasus DBD tertinggi di Asia Tenggara.

Salah satu provinsi di Indonesia yang masih endemis DBD yaitu Provinsi Jawa Timur. Letak ketinggian wilayah di Provinsi Jawa Timur dari permukaan air laut terbagi menjadi 3 (tiga) bagian yaitu dataran tinggi, dataran sedang dan dataran rendah. Salah satu kota yang terletak di wilayah dataran tinggi yaitu
Kota Batu. Kota Batu terdiri dari 3 (tiga) kecamatan, yaitu: Kecamatan Batu, Kecamatan Junrejo, dan Kecamatan Bumiaji. Kecamatan Bumiaji berada pada ketinggian rata-rata $1.062 \mathrm{mdpl}$. Kelurahan yang memiliki ketinggian paling rendah dibandingkan dengan kelurahan lainnya yaitu Kelurahan Giripurno yang berada pada ketinggian 700 mdpl. Menurut laporan kasus infeksi dengue Dinas Kesehatan Kota Batu tahun 2016 di kelurahan Giripurno terjadi kasus Demam Dengue (DD) sebanyak 23 kasus dan kasus DBD sebanyak 5 kasus. Sedangkan kelurahan yang berada di wilayah paling tinggi yaitu Kelurahan Sumber Brantas dengan ketinggian $1.700 \mathrm{mdpl}$, namun di Kelurahan Sumber Brantas tidak ditemukan adanya kasus infeksi dengue. 
Kelurahan tertinggi ke dua yaitu kelurahan Tulungrejo dengan ketinggian 1.500 mdpl. Menurut laporan kasus infeksi dengue Dinas Kesehatan Kota Batu tahun 2016 di kelurahan Tulungrejo ditemukan adanya kasus DD sebanyak 11 kasus.

Berdasarkan Dirjen P2PL Kementerian Kesehatan RI di tempat dengan ketinggian lebih dari $1.000 \mathrm{mdpl}$ semestinya tidak ditemukan nyamuk Aedes aegypti yang merupakan vektor penular penyakit DD atau DBD. Karena pada ketinggian tersebut suhu udara terlalu rendah sehingga mempengaruhi pertumbuhan nyamuk dan pertumbuhan virus di tubuh nyamuk. Selain ketinggian tempat, kelembaban udara juga mempengaruhi umur nyamuk.

Penelitian yang dilakukan oleh LozanoFuentes et al., (2012) mengemukakan bahwa hasil dari observasi yang mereka lakukan di Mexico, Ae. Aegypti cukup banyak ditemukan pada ketinggian 1.700 meter dan masih ditemukan walaupun sedikit hingga wilayah dengan ketinggian 2.130 meter.

Maka peneliti ingin melakukan penelitian yang bertujuan untuk menggambarkan distribusi tempat perindukan Aedes $s p$. pada dataran tinggi dan rendah studi kasus di Kelurahan Tulungrejo dan Kelurahan Giripurno Kecamatan Bumiaji Kota Batu Tahun 2017.

\section{METODE PENELITIAN}

Penelitian ini merupakan penelitian survei deskriptif dengan pendekatan cross sectional yaitu objek diobservasi satu kali saja dalam satu waktu.
Populasi dalam penelitian ini yaitu rumah penduduk di Kelurahan Tulungrejo dan Kelurahan Giripurno. Sampel yang diperiksa yaitu sebanyak 118 rumah yang terdiri dari 59 rumah di Kelurahan Tulungrejo dan 59 rumah di Kelurahan Giripurno. Teknik pengambilan sampel yang digunakan yaitu dengan cara systematic random sampling.

\section{HASIL DAN PEMBAHASAN}

\section{Kepadatan Larva Aedes sp.} Survey di Kelurahan Tulungrejo dilaksanakan pada 59 rumah dan ditemukan 90 kontainer. Perhitungan nilai House Index (HI) yaitu sebesar $1,7 \%$, Container Index (CI) sebesar 2,22\%, dan Breteau Index (BI) sebesar 3,39. Berdasarkan hasil perhitungan $\mathrm{HI}, \mathrm{CI}$, dan $\mathrm{BI}$ maka kepadatan larva Aedes sp. di Kelurahan Tulungrejo dikategorikan dalam kategori rendah (density figure=1).

Sedangkan survey yang dilakukan di Kelurahan Giripurno dilaksanakan pada 59 rumah dan ditemukan 74 kontainer. Perhitungan nilai House Index (HI) yaitu sebesar 15,25\%, Container Index (CI) sebesar 13,51\%, dan Breteau Index (BI) sebesar 16,95. Berdasarkan hasil perhitungan $\mathrm{HI}, \mathrm{CI}$, dan $\mathrm{BI}$ maka kepadatan larva Aedes sp. di Kelurahan Giripurno dikategorikan dalam kategori sedang (density figure=3). 
2. Karakteristik Habitat Larva Aedes sp.

Tabel 5

JENIS KONTAINER DI KELURAHAN TULUNGREJO

\begin{tabular}{|c|c|c|c|c|c|c|}
\hline \multirow{2}{*}{$\begin{array}{c}\text { Jenis } \\
\text { Kontainer }\end{array}$} & \multicolumn{4}{|c|}{ Keberadaan larva } & \multirow[b]{2}{*}{ Jumlah } & \multirow[b]{2}{*}{$\%$} \\
\hline & $(-)$ & $\%$ & $(+)$ & $\%$ & & \\
\hline TPA & & & & & & \\
\hline $\begin{array}{l}\text { - Bak } \\
\text { mandi }\end{array}$ & 60 & 66,67 & 2 & 2,22 & 62 & 68,88 \\
\hline - Ember & 3 & 3,33 & 0 & 0 & 3 & 3,33 \\
\hline - Dru & 2 & 2,22 & 0 & 0 & & \\
\hline $\begin{array}{c}\text { - Tempat } \\
\text { minum } \\
\text { burung }\end{array}$ & 21 & 23,33 & 0 & 0 & 21 & 23,33 \\
\hline $\begin{array}{c}\text { - Aqua } \\
\text { Rium }\end{array}$ & 2 & 2,22 & 0 & 0 & 2 & 2,22 \\
\hline Total & 88 & 97,78 & 2 & 2,22 & 90 & 100 \\
\hline
\end{tabular}

Berdasarkan tabel di atas dapat diketahui dari 90 kontainer yang diperiksa di Kelurahan Tulungrejo jenis kontainer TPA yang terbanyak yaitu bak mandi $(68,88 \%)$ dan jenis kontainer non TPA terbanyak berupa tempat minum burung $(23,33 \%)$. Jenis kontainer yang positif larva Aedes sp. hanya ditemukan pada bak mandi saja.

Tabel 6

JENIS KONTAINER DI KELURAHAN GIRIPURNO

\begin{tabular}{|c|c|c|c|c|c|c|}
\hline \multirow{2}{*}{$\begin{array}{c}\text { Jenis } \\
\text { Kontainer }\end{array}$} & \multicolumn{4}{|c|}{ Keberadaan larva } & \multirow{2}{*}{ Jumlah } & \multirow{2}{*}{$\%$} \\
\hline & $(-)$ & $\%$ & $(+)$ & $\%$ & & \\
\hline & & & & & & \\
\hline $\begin{array}{l}\text { - Bak } \\
\text { mandi }\end{array}$ & 49 & 66,22 & 10 & 13,51 & 59 & 79,73 \\
\hline - Ember & 3 & 4,05 & 0 & 0 & 3 & 4,05 \\
\hline $\begin{array}{l}\text { - Drum } \\
\text { Non TPA }\end{array}$ & 2 & 2,71 & 0 & 0 & 2 & 2,71 \\
\hline $\begin{array}{l}\text { - Tempat } \\
\text { minum } \\
\text { burung }\end{array}$ & 10 & 13,51 & 0 & 0 & 10 & 13,51 \\
\hline Total & 64 & 86,49 & 10 & 13,51 & 74 & 100 \\
\hline
\end{tabular}

Sedangkan di Kelurahan Giripurno diketahui dari 74 kontainer yang diperiksa, jenis kontainer TPA yang terbanyak yaitu bak mandi $(79,73 \%)$ dan jenis kontainer non TPA hanya tempat minum burung saja $(13,51 \%)$. Jenis kontainer yang positif larva Aedes sp. hanya ditemukan pada bak mandi saja. Dapat dilihat pada Tabel 6

Sejalan dengan penelitian yang dilakukan oleh Farahiyah (2014) menyatakan bahwa kontainer yang banyak ditemukan larva dibandingkan dengan kontainer yang lain yang berada di dalam rumah yaitu bak mandi. 
Tabel 7

BAHAN KONTAINER DI KELURAHAN TULUNGREJO

\begin{tabular}{|c|c|c|c|c|c|c|}
\hline \multirow{2}{*}{$\begin{array}{c}\text { Bahan } \\
\text { Kontainer }\end{array}$} & \multicolumn{4}{|c|}{ Keberadaan larva } & \multirow[b]{2}{*}{ Jumlah } & \multirow[b]{2}{*}{$\%$} \\
\hline & $(-)$ & $\%$ & $(+)$ & $\%$ & & \\
\hline Semen & 15 & 16,67 & 0 & 0 & 15 & 16,67 \\
\hline Keramik & 45 & 50 & 2 & 2,22 & 47 & 52,22 \\
\hline Plastik & 26 & 28,89 & 0 & 0 & 26 & 28,89 \\
\hline Kaca & 2 & 2,22 & 0 & 0 & 2 & 2,22 \\
\hline Total & 88 & 97,78 & 2 & 2,22 & 90 & 100 \\
\hline
\end{tabular}

Berdasarkan tabel di atas, bahan dasar kontainer yang paling banyak ditemukan di Kelurahan Tulungrejo adalah keramik yaitu sebanyak 47 kontainer atau $52,22 \%$ dari seluruh kontainer yang diperiksa.
Kontainer yang ditemukan positif larva Aedes $s p$. juga hanya pada kontainer yang berbahan dasar keramik yaitu sebanyak 2 kontainer atau $2,22 \%$.

Tabel 8

BAHAN KONTAINER DI KELURAHAN GIRIPURNO

\begin{tabular}{|c|c|c|c|c|c|c|}
\hline \multirow{2}{*}{$\begin{array}{c}\text { Bahan } \\
\text { Kontainer }\end{array}$} & \multicolumn{4}{|c|}{ Keberadaan larva } & \multirow[b]{2}{*}{ Jumlah } & \multirow[b]{2}{*}{$\%$} \\
\hline & $(-)$ & $\%$ & $(+)$ & $\%$ & & \\
\hline Semen & 26 & 35,13 & 2 & 2,71 & 28 & 37,84 \\
\hline Keramik & 23 & 31,08 & 8 & 10,81 & 31 & 41,89 \\
\hline Plastik & 15 & 20,27 & 0 & 0 & 15 & 20,27 \\
\hline Total & 64 & 86,48 & 10 & 13,52 & 74 & 100 \\
\hline
\end{tabular}

Sedangkan bahan dasar kontainer yang paling banyak ditemukan di Kelurahan Giripurno adalah keramik dan semen. Kontainer dengan bahan dasar keramik yaitu sebanyak 31 kontainer atau $41,89 \%$ dan kontainer dengan bahan dasar semen yaitu sebanyak 28 kontainer atau 37,84\%. Kontainer yang ditemukan positif larva Aedes $s p$. yaitu sebanyak 8 kontainer atau $10,81 \%$ berbahan dasar keramik dan 2 kontainer atau 2,71\% berbahan dasar semen.

Pemilihan tempat bertelur nyamuk Aedes spp. dipengaruhi oleh bahan dasar kontainer. Perilaku
Aedes spp. yang menempelkan telur pada dinding bagian dalam kontainer dan lebih menyukai permukaan dinding yang kasar. Permukaan dinding kontainer yang kasar lebih mudah dilekati telur dan ditumbuhi lumut sehingga lebih berpotensian menjadi tempat perkembangbiakan larva Aedes spp. (Kemenkes RI 2015 dalam Pahlepi).

Berdasarkan Tabel 9 diketahui hasil pengamatan di Kelurahan Tulungrejo didapatkan sebagian besar kontainer berwarna terang $(88,89 \%)$ dan kontainer yang positif larva Aedes $s p$. hanya pada kontainer yang berwarna terang. 
Tabel 9

KEBERADAAN LARVA AEDES $s p$. BERDASARKAN WARNA, LETAK, DAN KONDISI TUTUP KONTAINER DI KELURAHAN TULUNGREJO

\begin{tabular}{lccccccc}
\hline Karakteristik & \multicolumn{5}{c}{ Keberadaan larva } & Jumlah & $\%$ \\
\cline { 2 - 6 }$\quad$ Kontainer & $\mathbf{( - )}$ & $\%$ & $\mathbf{( + )}$ & $\mathbf{\%}$ & & \\
\hline Warna & & & & & & \\
$-\quad$ Terang & 78 & 86,67 & 2 & 2,22 & 80 & 88,89 \\
$-\quad$ Gelap & 10 & 11,11 & 0 & 0 & 10 & 11,11 \\
$\begin{array}{l}\text { Letak } \\
-\quad \text { Di dalam }\end{array}$ & 76 & 84,44 & 2 & 2,22 & 78 & 86,66 \\
$\quad \begin{array}{l}\text { rumah } \\
\text { Di luar }\end{array}$ & 12 & 13,33 & 0 & 0 & 12 & 13,33 \\
$\quad \begin{array}{l}\text { rumah } \\
\text { Kondisi tutup }\end{array}$ & & & & & & \\
$-\quad \begin{array}{l}\text { Tidak } \\
\quad \text { tertutup }\end{array}$ & 86 & 95,56 & 2 & 2,22 & 88 & 97,78 \\
$-\quad$ Tertutup & 2 & 2,22 & 0 & 0 & 2 & 2,22 \\
\hline
\end{tabular}

Jumlah kontainer yang diamati di Kelurahan Tulungrejo ditemukan lebih banyak di dalam rumah $(86,66 \%)$ dan kontainer yang positif larva Aedes sp. hanya pada kontainer yang berada di dalam rumah. Kondisi tutup kontainer ditemukan paling banyak kontainer yang tidak memiliki tutup $(97,78 \%)$ dan kontainer yang positif larva Aedes $s p$. hanya ditemukan pada kontainer yang tidak memiliki tutup.

Berdasarkan Tabel 10 diketahui hasil pengamatan di Kelurahan Giripurno didapatkan sebagian besar kontainer juga berwarna terang $(74,32 \%)$ dan ditemukan 10 kontainer yang positif larva Aedes sp. hanya pada kontainer yang berwarna terang.
Namun hasil penelitian yang dilakukan oleh Budiyanto (2012) di Sekolah Dasar Kecamatan Baturaja Timur, Kota Baturaja, kontainer yang berwarna gelap lebih banyak ditemukan larva Aedes aegypti.

Jumlah kontainer yang diamati di Kelurahan Giripurno ditemukan lebih banyak di dalam rumah $(86,66 \%)$ dan kontainer yang positif larva Aedes sp. hanya pada kontainer yang berada di dalam rumah.

Hal ini sejalan dengan penelitian yang dilakukan Pahlepi (2016) di Sekolah Dasar di Kota Palembang, jumlah kontainer yang ditemukan lebih banyak di dalam bangunan $(61,59 \%)$ dan kontainer yang terdapat larva Aedes $s p$. juga banyak ditemukan di dalam bangunan

$(15,31 \%)$.

Tabel 10

KEBERADAAN LARVA AEDES $s p$. BERDASARKAN WARNA, LETAK, DAN KONDISI TUTUP KONTAINER DI KELURAHAN GIRIPURNO

\begin{tabular}{|c|c|c|c|c|c|c|}
\hline \multirow{2}{*}{$\begin{array}{c}\text { Karakteristik } \\
\text { Kontainer }\end{array}$} & \multicolumn{4}{|c|}{ Keberadaan larva } & \multirow{2}{*}{ Jumlah } & \multirow{2}{*}{$\%$} \\
\hline & $(-)$ & $\%$ & $(+)$ & $\%$ & & \\
\hline \multicolumn{7}{|l|}{ Warna } \\
\hline - Terang & 45 & 60,81 & 10 & 13,51 & 55 & 74,32 \\
\hline - Gelap & 19 & 25,68 & 0 & 0 & 19 & 25,68 \\
\hline \multicolumn{7}{|l|}{ Letak } \\
\hline $\begin{array}{l}\text { - Di } \\
\text { dalam rumah }\end{array}$ & 54 & 72,98 & 10 & 13,51 & 64 & 86,49 \\
\hline $\begin{array}{l}\text { - Di } \\
\text { luar rumah }\end{array}$ & 10 & 13,51 & 0 & 0 & 10 & 13,51 \\
\hline \multicolumn{7}{|l|}{ Kondisi tutup } \\
\hline - Tidak tertutup & 62 & 83,78 & 10 & 13,51 & 72 & 97,29 \\
\hline - Tertutup & 2 & 2,71 & 0 & 0 & 2 & 2,71 \\
\hline
\end{tabular}


Berdasarkan Tabel 10 kondisi tutup kontainer ditemukan paling banyak kontainer yang tidak memiliki tutup $(97,29 \%)$ dan kontainer yang positif larva Aedes $s p$. juga hanya ditemukan pada kontainer yang tidak memiliki tutup.

Hal ini sejalan dengan penelitian Pahlepi (2016) di Sekolah Dasar di Kota Palembang ditemukan lebih banyak kontainer yang tidak memiliki tutup (96\%) dan kontainer yang positif larva Aedes sp. juga ditemukan pada kontainer yang tidak memiliki tutup (21,22\%).

Hasil pengukuran suhu air di dalam kontainer di Kelurahan Tulungrejo yaitu berkisar antara $18^{\circ} \mathrm{C}-23^{\circ} \mathrm{C}$. Kontainer yang ditemukan positif larva Aedes sp. adalah kontainer dengan suhu air $20^{\circ} \mathrm{C}$. Sedangkan hasil pengukuran suhu air di dalam kontainer di Kelurahan Giripurno yaitu berkisar antara $21^{\circ} \mathrm{C}-25^{\circ} \mathrm{C}$. Kontainer yang ditemukan positif larva Aedes sp. adalah kontainer dengan suhu air $21^{\circ} \mathrm{C}-23^{\circ} \mathrm{C}$.

Penelitian yang dilakukan oleh Mohammed dan Chadee (2011) untuk mengetahui pengaruh suhu air terhadap perkembangan larva $A e$. aegypti dalam skala laboratorium di Trinidad, West Indies diketahui suhu optimum berkisar antara $24^{\circ} \mathrm{C}-25^{\circ} \mathrm{C}$ dengan daya tetas sebesar $98 \%$.

Dengan demikian diketahui bahwa sudah terjadi perubahan perilaku berkembangbiak nyamuk Aedes $s p$. di Kecamatan Bumiaji Kota Batu. Mereka mampu bertahan hidup dan berkembangbiak meskipun dengan kondisi suhu air yang tidak optimum. Hasil pengukuran suhu udara di dalam rumah yang diperiksa di Kelurahan Tulungrejo yaitu berkisar antara $21^{\circ} \mathrm{C}-26^{\circ} \mathrm{C}$. Rumah yang ditemukan positif larva Aedes $s p$. adalah rumah dengan suhu udara $24^{\circ} \mathrm{C}$. Hasil pengukuran kelembaban udara di dalam rumah yang diperiksa yaitu berkisar antara 62\%-84\%. Rumah yang ditemukan positif larva Aedes $s p$. adalah hanya 1 rumah dengan kelembaban udara $67 \%$.

Sedangkan hasil pengukuran suhu udara di dalam rumah yang diperiksa di Kelurahan Giripurno yaitu berkisar antara $22^{\circ} \mathrm{C}-27^{\circ} \mathrm{C}$. Rumah yang ditemukan positif larva Aedes $s p$. adalah rumah dengan suhu udara optimum sebanyak 3 rumah (1 rumah dengan suhu udara $25^{\circ} \mathrm{C}$ dan 2 rumah dengan suhu udara $26^{\circ} \mathrm{C}$ ) dan rumah dengan suhu udara tidak optimum sebanyak 6 rumah (2 rumah dengan suhu udara $22^{\circ} \mathrm{C}$ dan 4 rumah dengan suhu udara $24^{\circ} \mathrm{C}$ ). Hasil pengukuran kelembaban udara di dalam rumah yang diperiksa yaitu berkisar antara 61\%-73\%. Rumah yang ditemukan positif larva Aedes $s p$. semuanya dengan kelembaban udara optimum yaitu diatas $60 \%$.

\section{Peta Distribusi Tempat Perindukan Larva Aedes sp.}

Pada Gambar 1 menunjukkan bahwa sebaran keberadaan positif larva Aedes $s p$. lebih banyak terdapat di Kelurahan Giripurno dengan jumlah 9 rumah. Sedangkan di Kelurahan Tulungrejo hanya ditemukan keberadaan positif larva Aedes $s p$. pada 1 rumah.

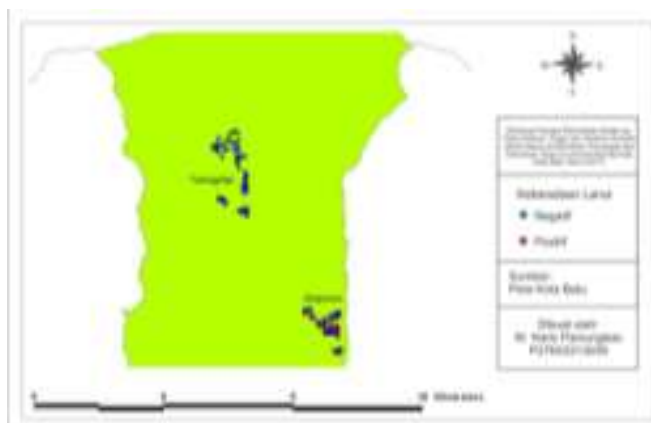

Gambar 1 Peta Distribusi Tempat Perindukan Aedes sp. di Kelurahan Tulungrejo dan Kelurahan Giripurno 
Pada Gambar 2 menunjukkan bahwa sebaran keberadaan positif larva Aedes $s p$. di Kelurahan Tulungrejo hanya ditemukan pada 1 rumah saja yaitu di Dusun Gondang.

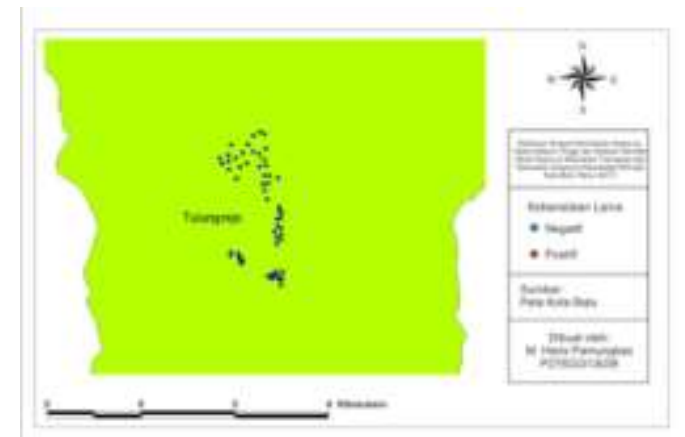

Gambar 2 Peta Distribusi Tempat Perindukan Larva Aedes sp. di Kelurahan Tulungrejo

Pada Gambar 3 menunjukkan bahwa sebaran keberadaan positif larva Aedes $s p$. di Kelurahan Giripurno ditemukan pada 9 rumah yang berada di 5 dusun yaitu Dusun Sumbersari, Dusun Krajan, Dusun Sabrangbendo, Dusun Durek, dan Dusun Sawahan. Sedangkan di Dusun Kedung tidak ditemukan keberadaan larva Aedes sp.

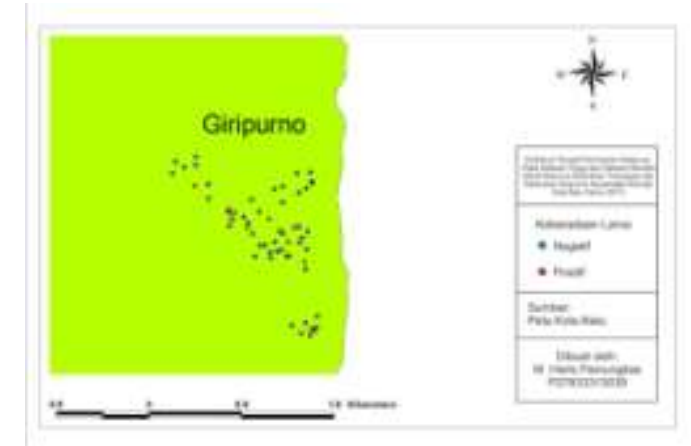

Gambar 3 Peta Distribusi Tempat Perindukan Larva Aedes sp. di Kelurahan Giripurno

Kelurahan Tulungrejo yang berada pada ketinggian $1.500 \mathrm{mdpl}$ lebih sedikit ditemukan keberadaan larva Aedes sp. jika dibandingkan dengan Kelurahan Giripurno yang berada pada ketinggian $700 \mathrm{mdpl}$. Maka dalam hal ini menunjukkan bahwa ketinggian suatu wilayah memiliki pengaruh terhadap kepadatan larva Aedes sp. Karena ketinggian suatu wilayah mempengaruhi suhu dan kelembaban udara wilayah tersebut. Nyamuk dapat bertahan hidup dan berkembangbiak juga dipengaruhi oleh faktor suhu dan kelembaban udara.

\section{KESIMPULAN DAN SARAN \\ Kesimpulan}

1. Berdasarkan perhitungan nilai $\mathrm{HI}, \mathrm{CI}$, dan BI $(1,7 \%, 2,22 \%$, dan 3,39) maka kepadatan larva Aedes $s p$. di Kelurahan Tulungrejo dikategorikan dalam kategori rendah (density figure=1). Kontainer yang ditemukan positif larva Aedes $s p$. yaitu bak mandi dengan bahan dasar keramik yang berwarna terang. Kontainer yang ditemukan positif larva Aedes 
$s p$. adalah kontainer dengan suhu air $20^{\circ} \mathrm{C}$. Suhu udara rumah positif larva Aedes sp. yaitu $24^{\circ} \mathrm{C}$ dan dengan kelembaban udara sebesar $67 \%$.

2. Berdasarkan perhitungan nilai $\mathrm{HI}, \mathrm{CI}$, dan BI (15,25\%, 13,51\%, dan 16,95) maka kepadatan larva Aedes sp. di Kelurahan Giripurno dikategorikan dalam kategori sedang (density figure=3). Kontainer yang ditemukan positif larva Aedes sp. yaitu bak mandi dengan bahan dasar keramik dan semen yang berwarna terang. Kontainer yang ditemukan positif larva Aedes sp. adalah kontainer dengan suhu air $21^{\circ} \mathrm{C}-23^{\circ} \mathrm{C}$. Suhu udara rumah positif larva Aedes $s p$. yaitu ditemukan baik pada suhu optimum maupun dibawah suhu optimum. Sedangkan kelembaban udara rumah positif larva Aedes sp. yaitu termasuk dalam kelembaban optimum.

3. Sebaran keberadaan rumah positif larva Aedes sp. di Kelurahan Tulungrejo hanya ditemukan pada 1 rumah saja yaitu di Dusun Gondang. Sedangkan sebaran keberadaan rumah positif larva Aedes sp. di Kelurahan Giripurno ditemukan pada 9 rumah yang berada di 5 dusun yaitu di Dusun Sumbersari, Dusun Krajan, Dusun Sabrangbendo, Dusun Durek, dan Dusun Sawahan. Sedangkan di Dusun Kedung tidak ditemukan keberadaan larva Aedes sp.

\section{Saran}

1. Perlu dilakukan penelitian lebih lanjut mengenai faktor-faktor yang mempengaruhi sebaran perindukan nyamuk Aedes sp. di wilayah dataran tinggi $>1.000$ mdpl.

2. Perlu adanya kewaspadaan dini pencegahan DBD di wilayah dataran tinggi.

\section{DAFTAR PUSTAKA}

Badan Pusat Statistik Kota Batu, 2016. Statistik Daerah Kecamatan Bumiaji 2016.

Badan Pusat Statistik Kota Batu, 2016. Statistik Daerah Kota Batu 2016.

Budiyanto A, 2012. Perbedaan Warna
Kontainer Berkaitan dengan Keberadaan Jentik Aedes aegypti di Sekolah Dasar. Loka Litbang P2B2 Baturaja.

Dirjen P2PL Depkes RI, 2005. Pencegahan dan Pemberantasan Demam Berdarah Dengue di Indonesia.

Dirjen P2PL Kemenkes RI, 2011. Modul Pengendalian Demam Berdarah Dengue.

Dirjen P2PL Kemenkes RI, 2013. Pedoman Survei Entomologi Demam Berdarah Dengue dan Kunci Identifikasi Nyamuk Aedes.

Farahiyah M, 2014. Analisis Spasial Faktor Lingkungan dan Kejadian $D B D$ di Kabupaten Demak. Semarang, Magister Kesehatan Lingkungan Universitas Diponegoro.

Hadinegoro, Sri Rezeki, Ismoedijanto Moedjito dan Alex Chairulfatah, 2014. Pedoman Diagnosis dan Tata Laksana Infeksi Virus Dengue pada Anak. Badan Penerbit Ikatan Dokter Anak Indonesia.

Lozano-Fuentes, S., Hayden, M. H., Welsh-Rodriguez, C., OchoaMartinez, C., Berenice TapiaSantos, B., Kobylinski, K.C., Uejio, C. K., Zielinski-Gutierrez, E., Monache, L. D., Monaghan, A,J., Steinhoff, D. F., and Eisen L. (2012) The Dengue Virus Mosquito Vector Aedes aegypti at High Elevation in Me'xico. Am. J. Trop. Med. Hyg. 87(5) pp.902-909.

Mohammed A, Chadee DD. 2011. Effects of Different Temperature Regimens on The Development of Aedes aegypti (L.) (Diptera: Culicidae) mosquitoes. Acta Trop. 119 (2011) : 38-43.

Notoatmodjo, Soekidjo, 2014. Metodologi Penelitian Kesehatan. Jakarta, Rineka Cipta. Cetakan Kedua.

Pahlepi, R Irpan, 2016. Kepadatan Dan Karakteristik Habitat Larva Aedes Spp. Pada Sekolah Dasar Di Kota Palembang. Bogor, Sekolah Pascasarjana Institut Pertanian Bogor: 12-17. 
Peraturan Menteri Kesehatan Republik Indonesia Nomor 374 Tahun 2010 Tentang Pengendalian Vektor.

Pusat Data dan Surveilans Epidemiologi Kemenkes RI, 2010. Demam Berdarah Dengue di Indonesia Tahun 1968-2009, Jendela Epidemiologi. 2: 1-3.

Santoso dan Yahya, 2011. Analisis Kejadian Luar Biasa (KLB) Demam Berdarah Dengue (DBD) di Wilayah Puskesmas Rawasari Kota Jambi Bulan Agustus 2011, Jurnal Ekologi Kesehatan. 10: $250-251$.
Sucipto, Cecep, 2011. Vektor Penyakit Tropis. Yogyakarta, Gosyen Publishing.

Vezzani D, Carbajo AE. 2008. Aedes aegypti, Aedes albopictus and dengue in Argentina: current knowledge and future directions. Mem Inst Oswaldo Cruz. 103(1): 66-74.

Widyastuti, Palupi, 2005. Pencegahan dan Pengendalian Dengue dan Demam Berdarah Dengue: Panduan Lengkap. Jakarta, EGC. 